\title{
Contribution of Calcium Ions to P2X Channel Responses
}

\author{
Terrance M. Egan ${ }^{1,2}$ and Baljit S. Khakh ${ }^{1}$ \\ ${ }^{1}$ Medical Research Council, Laboratory of Molecular Biology, Cambridge CB2 2QH, United Kingdom, and ${ }^{2}$ Department of Pharmacological and \\ Physiological Science, St. Louis University School of Medicine, St. Louis, Missouri 63104
}

\begin{abstract}
$\mathrm{Ca}^{2+}$ entry through transmitter-gated cation channels, including ATP-gated P2X channels, contributes to an array of physiological processes in excitable and non-excitable cells, but the absolute amount of $\mathrm{Ca}^{2+}$ flowing through P2X channels is unknown. Here we address the issue of precisely how much $\mathrm{Ca}^{2+}$ flows through $\mathrm{P} 2 \mathrm{X}$ channels and report the finding that the ATP-gated P2X channel family has remarkably high $\mathrm{Ca}^{2+}$ flux compared with other channels gated by the transmitters ACh, serotonin, protons, and glutamate. Several homomeric and heteromeric P2X channels display fractional $\mathrm{Ca}^{2+}$ currents equivalent to NMDA channels, which hitherto have been thought of as the largest source of transmitter-activated $\mathrm{Ca}^{2+}$ flux. We further suggest that NMDA and P2X channels may use different mechanisms to promote $\mathrm{Ca}^{2+}$ flux across membranes. We find that mutating three critical polar amino acids decreases the $\mathrm{Ca}^{2+}$ flux of $^{2}$ $\mathrm{P} 2 \mathrm{X}_{2}$ receptors, suggesting that these residues cluster to form a novel type of $\mathrm{Ca}^{2+}$ selectivity region within the pore. Overall, our data identify P2X channels as a large source of transmitter-activated $\mathrm{Ca}^{2+}$ influx at resting membrane potentials and support the hypothesis that polar amino acids contribute to $\mathrm{Ca}^{2+}$ selection in an ATP-gated ion channel.
\end{abstract}

Key words: ATP; P2X; synapse; calcium; permeability; channel

\section{Introduction}

Transmitter-gated cation channels (TGCCs) are key transmembrane proteins of excitable and non-excitable cells. Mammalian TGCCs can be divided into three main families on the basis of gene and protein sequences and known and predicted channel structures (Green et al., 1998). Cys-loop receptors for ACh, serotonin, GABA, and glycine form one family, and glutamate-gated channels form the second (Green et al., 1998). The third major family of mammalian TGCCs are the ATP-gated P2X channels that have a relatively simple structure compared with the other two families. To date, the quaternary structure of the channel is thought to be composed of specific combinations of three of the seven $\left(\mathrm{P}_{2} \mathrm{X}_{1}-\mathrm{P} 2 \mathrm{X}_{7}\right)$ known subunits (Nicke et al., 1998; Stoop et al., 1999; Jiang et al., 2003). Each subunit possesses two transmembrane segments (North, 2002), the second of which is thought to line the ion channel pore (Rassendren et al., 1997; Egan et al., 1998). P2X channels are widely expressed throughout the nervous system and underlie fast ATP neurotransmission at some neuro-neuronal synapses (Norenberg and Illes, 2000; North, 2002). For instance, $\mathrm{P}_{2} \mathrm{X}_{2}$ channels mediate an EPSP between myenteric neurons (Galligan and Bertrand, 1994; Khakh et

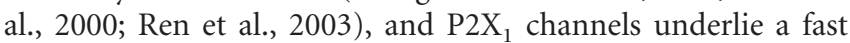
excitatory junction potential at neuro-effector junctions (Brain et al., 2002; Lamont and Wier, 2002; Lamont et al., 2003). In

Received Dec. 9, 2003; revised Feb. 17, 2004; accepted Feb. 17, 2004.

We thank Drs. N. Unwin, D. Bowser, and J. Fisher for comments, L. P. Wollmuth for practical advice on measuring Pf \%, and L. Lagnado for loan of equipment. This work was supported by the Medical Research Council (UK), a European Molecular Biology Organization Young Investigator Award, the Human Frontier Science Program, and the National Institutes of Health.

Correspondence should be addressed to Baljit $\mathrm{S}$. Khakh, Medical Research Council, Laboratory of Molecular Biology, Hills Road, Cambridge CB2 20H, UK. E-mail: bsk@mrc-Imb.cam.ac.uk.

DOI:10.1523/JNEUROSCI.5429-03.2004

Copyright $\odot 2004$ Society for Neuroscience $\quad$ 0270-6474/04/243413-08\$15.00/0 addition, P2X channels are found presynaptically where they modulate neurotransmitter release (Gu and MacDermott, 1997; Khakh and Henderson, 1998; MacDermott et al., 1999; Hugel and Schlichter, 2000; Kato and Shigetomi, 2001; Nakatsuka and $\mathrm{Gu}, 2001$; Khakh et al., 2003). In many instances, the physiological response is triggered by the influx of $\mathrm{Ca}^{2+}$ through $\mathrm{P} 2 \mathrm{X}$ channels; prime examples include presynaptic responses at neuro-neuronal synapses and postsynaptic responses at neuroeffector junctions.

Most TGCCs, including P2X channels, have $\mathrm{Ca}^{2+}$ permeabilities equal to or greater than those of the 100 -fold more abundant $\mathrm{Na}^{+}$(Burnashev, 1998). When these channels open, $\mathrm{Ca}^{2+}$ moves down its electrochemical gradient and into the cell. The resulting influx of $\mathrm{Ca}^{2+}$ exerts wide-ranging physiological effects that can last for seconds, days, or weeks (Berridge et al., 2003), adding a spatial and temporal dimension to transmitter signaling that may outlast the initial millisecond time scale surge of neurotransmitter and the accompanying depolarization by factors of $>10^{9}$. Previous studies revealed that ATP gates a transmembrane $\mathrm{Ca}^{2+}$ flux pathway (Benham and Tsien, 1987; Rogers and Dani, 1995) that subsequently was shown to contribute to the panoply of physiological responses in cells throughout the body, including neurons, muscle, glia, immune cells, and epithelia (Khakh, 2001; Inoue, 2002; North, 2002; Schwiebert and Zsembery, 2003). However, a comprehensive examination of $\mathrm{Ca}^{2+}$ flux through the ATP-gated P2X channel family is not reported, and there is little quantitative information about how much $\mathrm{Ca}^{2+}$ flows through P2X channels in relation to other TGCCs.

In the present study, we directly measured $\mathrm{Ca}^{2+}$ flow through 11 functional recombinant $\mathrm{P} 2 \mathrm{X}$ channels and compared these values with other TGCCs. We used patch-clamp photometry to measure fractional calcium currents (Pf\%) carried by TGCCs (Schneggenburger et al., 1993). Our data suggest that, on average, 

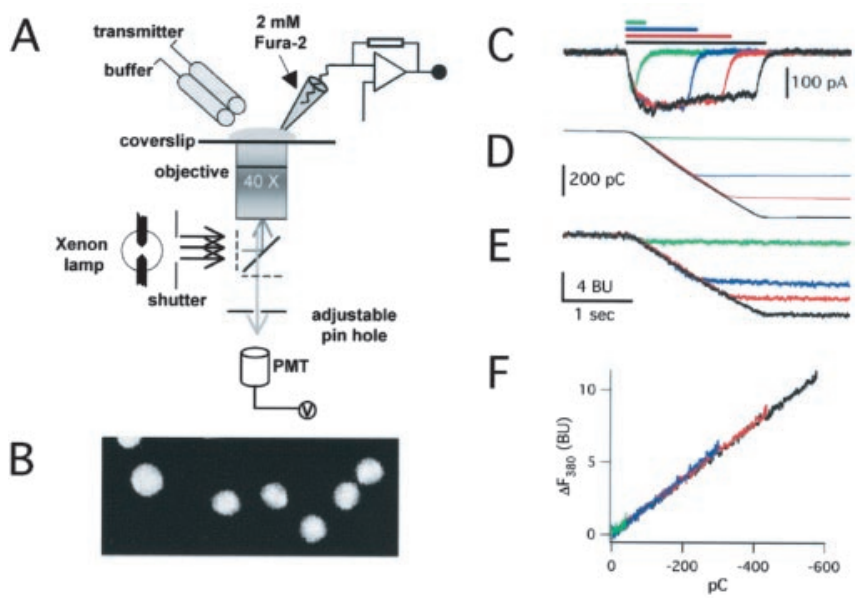

Figure 1. Determination of fractional $\mathrm{Ca}^{2+}$ currents. $A$, Representation of the experimental setup used for measuring Pf\%. HEK293 cells expressing molecularly defined channels were plated onto glass coverslips and patch clamped with electrodes filled with intracellular solution containing $2 \mathrm{~mm}$ fura-2. ATP was applied rapidly using an automated fast solution switcher. Photons were captured through a $40 \times$ objective lens. The emitted light was filtered and directed toward a photo multiplier attached to the microscope side port, and photon counts were measured in volts. The bottom photomicrograph $(B)$ shows images of Fluoresbrite beads that were used to calibrate the voltage signal produced by the photomultiplier tube (PMT): for illustration purposes, the images shown were captured on a confocal microscope with the iris fully open. The beads have a mean diameter of $4.6 \mu \mathrm{m}$. C, ATP-evoked currents of increasing duration in pure $\mathrm{Ca}^{2+}$ extracellular solutions at $\mathrm{P} 2 \mathrm{X}_{2}$ channels. The holding potential was -60 $\mathrm{mV}$. D shows the integral of these currents, and $E$ shows the corresponding changes in fura- 2 fluorescence at $380 \mathrm{~nm}$ : the time course of the change in $F_{380}$ matches the time course of $Q_{T}$ for all of the traces. $F, A$ graph of $\Delta F_{380}$ and $Q_{T}$ for each of the traces shown in $C-E$. They all superimpose and fall on a straight line. The slope of this line represents the proportionality constant between $Q_{T}$ and $\Delta F_{380}$ bead units per picocoulomb.

P2X channels are the most $\mathrm{Ca}^{2+}$-permeable TGCCs and suggest that polar amino acids may provide the counter charges needed to partially dehydrate $\mathrm{Ca}^{2+}$ ions in a narrow part of the pore.

\section{Materials and Methods}

Molecular biology. The stable cell lines used were HEK293 cells expressing the rat $5-\mathrm{HT}_{3 \mathrm{~A}}$ channel (Sarah Lummis, Medical Research Council, Laboratory of Molecular Biology, Cambridge, UK) or the human $\alpha 4 \beta 2$ nicotinic channel (Alison Rush, Research Labs, San Diego, CA). Wild-type and mutant rat $\mathrm{P} 2 \mathrm{X}_{2} \mathrm{cDNAs}$ were available from previous work; these mutants were generated using routine methods. Drs. Richard Evans (University of Leicester, Leicester, UK), R. Alan North (Institute of Molecular Physiology, Sheffield, UK), David Julius (University of California San Francisco, San Francisco, CA), Thomas Küner (MPI, Hiedelberg, Germany), and Henry A. Lester (California Institute of Technology, Pasadena, CA) supplied cDNAs encoding human $\mathrm{P}_{2} \mathrm{X}_{1}$, human $\mathrm{P}_{2} \mathrm{X}_{4}$, rat vanilloid receptor 1 (VR1), rat NR1/NR2A, and chick $\alpha 4 / \beta 2$ nicotinic channels, respectively. Plasmid cDNAs were transfected into HEK293 cells plated on $35 \mathrm{~mm}$ plastic culture dishes using Effectene (Qiagen, West Sussex, UK) and following the protocol of the manufacturer.

Patch-clamp photometry. The experimental setup is depicted in Figure $1 \mathrm{~A}$. Cells expressing the protein of interest were replated at low density onto $13 \mathrm{~mm}$ borosilicate glass coverslips (BDH Chemicals, Poole, UK) 12-18 hr before the start of the experiment. Coverslips were transferred to a recording chamber positioned on the stage of a Nikon (Tokyo, Japan) Diaphot 200 inverted microscope equipped with a Fluor $40 \times$ objective, $100 \mathrm{~W}$ xenon lamp, Uniblitz (Rochester, NY) shutter, liquid light guide, and custom-made coupling. In most cases, whole-cell current was recorded at a holding potential of $-55 \mathrm{mV}$ using an Axopatch 1-D amplifier (Axon Instruments, Foster City, CA) and a low resistance (1.5-5 M $\Omega$ ) glass microelectrode filled with an intracellular solution of the following composition (in $\mathrm{mm}$ ): $140 \mathrm{CsCl}, 10$ tetraethylammonium Cl, 10 HEPES, 2 fura- $2 \mathrm{~K}^{5}$ (lot 3491-11; Molecular Probes, Eugene, OR), and $4.8 \mathrm{CsOH}, \mathrm{pH}$ 7.3. Previous findings demonstrate that fura- 2 reaches a steady-state intracellular concentration in HEK293 cells after 5-6 min of passive diffusion from the recording electrode (Schneggenburger et al., 1993; Burnashev et al., 1995; Schneggenburger, 1998; Frings et al., 2000). Consistent with this, we saw no increase in the steady level of resting fura-2 fluorescence $10 \mathrm{~min}$ after going whole cell (data not shown), and we always waited 10 min after rupturing the patch before continuing with the experiment. Agonists were applied for 0.2-4.0 sec once every $2-3$ min using triple-barreled theta glass and a rapid solution changer system (Perfusion Fast-Step System SF-77; Warner Instruments, Hamden, CT). The extracellular bath solution contained the followinig (in mM): $140 \mathrm{NaCl}, 1 \mathrm{MgCl}_{2}, 2 \mathrm{CaCl}_{2}, 10$ HEPES, 10 glucose, and $5 \mathrm{NaOH}$ to adjust the $\mathrm{pH}$ to 7.4 .

We determined fractional calcium current by simultaneously measuring the total membrane current and the change in emission of fura- 2 excited at $380 \mathrm{~nm}\left(F_{380}\right)$. Previous work shows that $\mathrm{Pf} \%$ values can be determined accurately with a single excitation wavelength (Schneggenburger et al., 1993). An advantage of this technique is that it does not require that the absolute change in $\left[\mathrm{Ca}^{2+}\right]_{\mathrm{i}}$ be quantified directly and thus avoids the time-consuming step needed to switch between excitation wavelengths. Rather, $\mathrm{Ca}^{2+}$ flux is measured by monitoring the change in fluorescence of fura- 2 at a single wavelength, thus allowing for high time resolution measurements with a single photomultiplier tube. Whole-cell fluorescence at $510 \mathrm{~nm}$ was collected using a model 714 Photomultiplier Detection System (Photon Technology International, South Brunswick, NJ). The excitation filter was 380AF10 (XF1094), the dichroic was 415DCLP (XF2002), and the emitter was 510WB40 (XF3043; all from Omega Optical, Brattleboro, VT). Background fluorescence was minimized by limiting the field of view of the photomultiplier tube to the immediate vicinity of the cell under investigation using an adjustable pinhole. We controlled for day-to-day variations in the efficiency of our system by normalizing the biological signal to that of the average fluorescence of five carboxy Bright Blue 4.6 $\mu \mathrm{m}$ microspheres (Polysciences, Warrington, PA) that had settled on the bottom of the bath chamber filled with the normal extracellular solution (Fig. $1 B$ ). Thus, in keeping with previous work (Schneggenburger et al., 1993), we present changes in fura-2 fluorescence in bead units (BU) rather than volts. All data were sampled at $5 \mathrm{kHz}$ using Digitdata 1200 hardware and pClamp 8.0 software by Axon Instruments; fluorescence was low-pass filtered offline at $300 \mathrm{~Hz}$.

Data analysis. The Pf\% was calculated as follows:

$$
P f \%=\frac{Q_{\mathrm{Ca}_{\mathrm{a}}}}{\mathrm{Q}_{\mathrm{T}}} 100,
$$

where $Q_{\mathrm{T}}$ (the integral of the ligand-gated ionic current) and $Q_{\mathrm{Ca}}$ are given by the following:

$$
\begin{aligned}
& \int I_{\mathrm{ATP}}(t) d \mathrm{t}=Q_{\mathrm{T}}, \\
& Q_{\mathrm{Ca}}=\frac{\Delta F_{380}}{F_{\max }}
\end{aligned}
$$

$F_{\max }$ is the calibration constant used to relate $\Delta Q_{\mathrm{Ca}}$ to $\Delta F_{380}$. It was calculated in a separate series of experiments under conditions in which $Q_{\mathrm{T}}$ is expected to equal $Q_{\mathrm{Ca}}$ (Fig. $\left.1 C-E\right)$. This was achieved by the following: (1) measuring ATP-gated membrane current and fluorescence from cells expressing either $\mathrm{P}_{2} \mathrm{X}_{2}$ or $\mathrm{P}_{2} \mathrm{X}_{4}$ channels; (2) holding these cells at a membrane potential $(-60 \mathrm{mV})$ at which the outward flow of ions is negligible; and (3) replacing extracellular $\mathrm{Na}^{+}$with $112 \mathrm{mM} \mathrm{Ca}^{2+}$. Under these conditions, ATP elicits membrane currents carried exclusively by $\mathrm{Ca}^{2+}$, and $F_{\max }$ can be determined from the slope of the plot of $Q_{\mathrm{T}}$ versus $F_{380}$ (Fig. $\left.1 F\right) . F_{\max }$, measured in this way, was $0.012 \pm 0.002$ $\mathrm{BU} / \mathrm{nC}(n=37)$. Data were analyzed in Clampfit 8.1 (Axon Instruments), and calculations were performed using macros written in Igor Pro (WaveMetrics, Lake Oswego, OR). Results are reported as mean \pm SEM for the number of cells $(n)$ included in the study. Pf\% was often measured many times in a single cell; these measures were then averaged to give the Pf\% for the individual cell. Significant differences among 

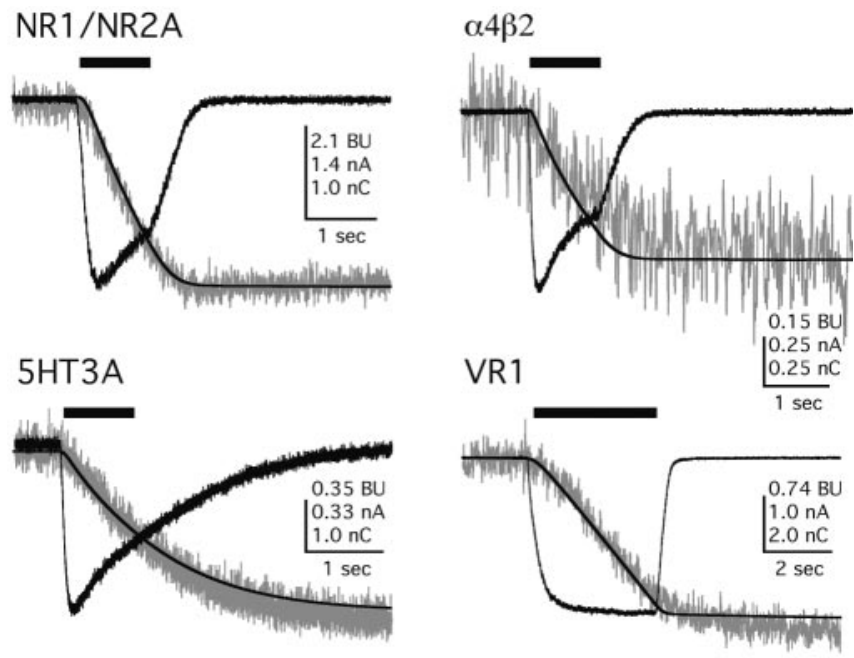

Figure 2. Representative traces for $Q_{T}$ and $\Delta F_{380}$ at transmitter-gated channels. For all panels in this figure, the black traces are transmitter-evoked currents (in amperes) and the integral of the current $Q_{T}$ (in nanocoulombs), whereas the gray traces are the $\Delta F_{380}$ (in bead units). Appropriate agonists were applied for the times indicated by the solid bars above the traces. These agonists were as follows: $100 \mu \mathrm{m}$ glutamate in $0 \mathrm{~mm}$ extracellular $\mathrm{Mg}^{2+}$ with 100 $\mu \mathrm{m}$ glycine for NR1/NR2A, $100 \mu \mathrm{m}(-)$-nicotine for $\alpha 4 \beta 2,10 \mu \mathrm{m}$ serotonin for $5-\mathrm{HT}_{3 \mathrm{~A}}$, and pH 5.5 for VR1.

groups were determined by one-way ANOVA with Tukey's post hoc or the Student's $t$ test. A $p$ value of $<0.01$ was considered significant.

Chemicals. All chemicals used were from Tocris Cookson (Bristol, UK), Molecular Probes, or Sigma.

\section{Results}

Pf\% for channels gated by glutamate, serotonin, acetylcholine, and protons

Patch-clamp photometry is the only method providing an absolute measure of $\mathrm{Ca}^{2+}$ flux for ion channels that is independent of cell type, endogenous buffer capacity, channel density, and current amplitude (Schneggenburger et al., 1993). It is also superior to reversal potential-based methods because the measurements are made in physiological solutions at resting membrane potentials and because the values for flux do not make GoldmanHodgkin-Katz assumptions (Frings et al., 2000). Using patchclamp photometry, we began by measuring the fractional $\mathrm{Ca}^{2+}$ current of nicotinic $\alpha 4 \beta 2$, serotonin $5-\mathrm{HT}_{3 \mathrm{~A}}$, proton-gated VR1, and glutamate NR1/NR2A channels (Fig. 2) because these are well characterized channels that are known to transport $\mathrm{Ca}^{2+}$ across membranes in neurons (Burnashev, 1998; MacDermott et al., 1999; Montell, 2001; Reeves and Lummis, 2002). Our Pf\% values for the human $\alpha 4 \beta 2$, chick $\alpha 4 \beta 2$, and rat NR1/NR2A were $3.1 \pm 0.6(n=5), 3.1 \pm 0.8(n=4)$, and $14.1 \pm 0.9 \%(n=15)$ and are in excellent agreement with published reports (Ragozzino et al., 1998; Jatzke et al., 2002; Lax et al., 2002; Watanabe et al., 2002). The Pf\% values of the rat $5-\mathrm{HT}_{3 \mathrm{~A}}$ and rat VR1 channels are not reported previously, and we find them to be $4.7 \pm 0.3 \%(n=8)$ and $3.5 \pm 0.3 \%(n=30)$, respectively. Together, these data validate our methods and provide guideposts by which to compare the $\mathrm{Ca}^{2+}$ flux of different TGCC families.

\section{Pf\% for homomeric P2X channels gated by ATP}

Previous detailed experiments have shown that intact HEK293 cells loaded with cell-permeable $\mathrm{Ca}^{2+}$ indicator dyes express endogenous P2Y receptors that mobilize intracellular $\mathrm{Ca}^{2+}$ in a
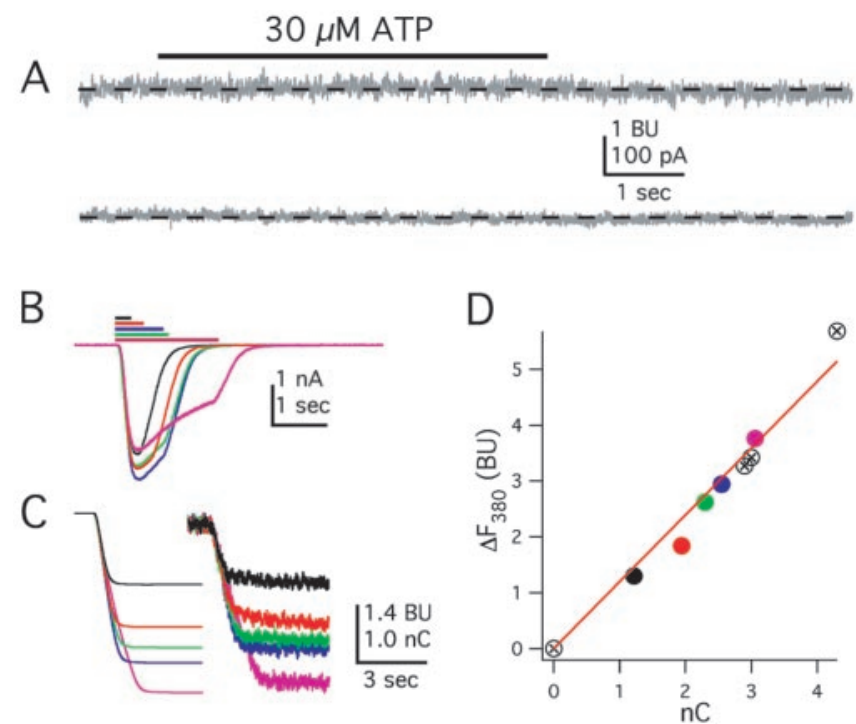

Figure 3. Controls and calibrations for measurements of $P f \%$ at $P 2 X$ channels. $A$, Lack of effect of $30 \mu \mathrm{m}$ ATP on membrane current (bottom trace) and $F_{380}$ (top trace) in a mocktransfected HEK293 cell. $B-D$, Representative traces for an HEK293 cell expressing P2X 2 channels and activated with $10 \mu \mathrm{m}$ ATP for increasing durations, as indicated by the length of the bars in $B$. B shows the current traces (for clarity, we show only 5 of the 9 traces), and ( shows the corresponding integrated currents $\left(Q_{T}\right.$, left traces) and changes in fluorescence $\left(\Delta F_{380}\right.$, right traces). $D$ shows a plot of $\Delta F_{380}$ versus $Q_{T}$. The data fall on a straight line, as expected if $P 2 X$ channels are the only source of $C a^{2+}$. The traces and data are colored coded in $B-D$ so that any individual response can be compared across all graphs. In $D$, there are four additional data points that, for the sake of simplicity, are not illustrated in $B$ and $C$.

G-protein-dependent manner (Fischer et al., 2003; He et al., 2003). We measured the effect of $30 \mu \mathrm{M}$ ATP on untransfected and mock-transfected HEK293 cells to determine whether P2X channel-independent changes in $\left[\mathrm{Ca}^{2+}\right]_{\mathrm{i}}$ occur under the conditions used in the experiments described in this study. In so doing, we used exactly the same experimental conditions used for the measurement of Pf\% values, which is whole-cell dialysis of the cell with intracellular solution containing fura for at least $10 \mathrm{~min}$. Figure $3 A$ shows that an application of $30 \mu \mathrm{M}$ ATP had no measurable affect on either the holding current (bottom trace) or $F_{380}$ (top trace) in a mock-transfected cell. In a sample of eight cells, whole-cell fluorescence measured at $4 \mathrm{sec}$ after the start of an application of $30 \mu \mathrm{M}$ ATP was $99.9 \pm 0.2 \%$ of that measured immediately before the start; this translates to a negligible decrease of $0.007 \pm 0.015 \mathrm{BU}$ in fura fluorescence, which implies negligible release of $\mathrm{Ca}^{2+}$ from intracellular stores and no presence of endogenous P2X channels (Fig. 3A, bottom trace). We suggest that differences between our experiments showing negligible contribution of $\mathrm{P} 2 \mathrm{Y}$ receptors and previous studies (Fischer et al., 2003; He et al., 2003) are attributable to the unavoidable experimental requirements of our approach, namely complete intracellular dialysis of the cell constituents (Schneggenburger et al., 1993). We expect that, under these conditions, metabotropic ATP receptor effects are impaired.

We saw robust inward currents and decreases in $F_{380}$ in transfected cells expressing P2X channels. Current and fluorescence were measured while applying $10 \mu \mathrm{M}$ ATP for varying lengths of time $(0.2-3.5 \mathrm{sec}$, as indicated by the lengths of the solid bars in Fig. $3 B$ ) to a HEK293 cell expressing homomeric $\mathrm{P}_{2} \mathrm{X}_{2}$ channels (Fig. 3B). Of critical importance are data showing that the time course of the decrease in $F_{380}$ mirrored that of the integral of the ATP-gated current (Fig. 3C) as expected if $\mathrm{Ca}^{2+}$ enters through 

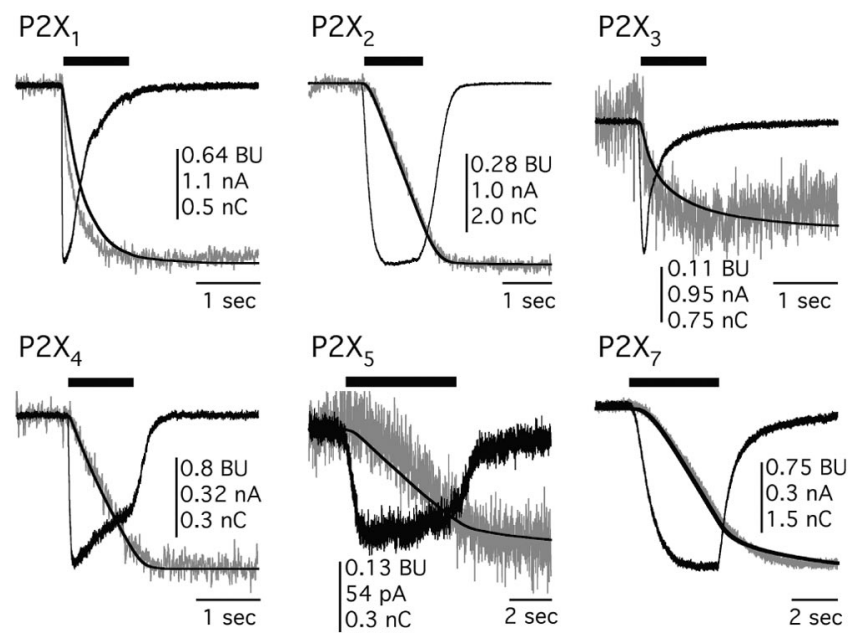

Figure 4. Representative traces for $\mathrm{Q}_{T}$ and $\Delta F_{380}$ at homomeric $\mathrm{P} 2 \mathrm{X}$ channels. For all panels in this figure, the black traces are transmitter-evoked currents (in amperes) and the integral of the current $Q_{T}$ (in nanocoulombs), whereas the gray traces are the $\Delta F_{380}$ (in bead units). Appropriate agonists were applied for the times indicated by the solid bars above the traces. These agonists were as follows: $3 \mu \mathrm{m}$ ATP for P2X and P2X $; 30 \mu \mathrm{m} \mathrm{ATP} \mathrm{for} \mathrm{P2X} 2$, P2X $\mathrm{X}_{4}$, and P2X and $100 \mu \mathrm{m}$ benzoylbenzoyl ATP for P2X .

P2X 2 channels (Schneggenburger et al., 1993). Furthermore, the plot of $\Delta F_{380}$ versus $Q_{\mathrm{T}}$ was linear (Fig. $3 D$ ). Both results suggest that the P2X channels are the sole source of the rise in $\left[\mathrm{Ca}^{2+}\right]_{\mathrm{i}}$. This conclusion is supported by data showing that calciuminduced calcium release is negligible in HEK293 cells studied with fura-2 (Alonzo et al., 2003). Our finding that ATP activation of endogenous P2Y receptors does not affect $\left[\mathrm{Ca}^{2+}\right]_{\text {i. }}$ under our experimental conditions probably reflects disruption of a signaling cascade mechanism caused by the obligatory $10 \mathrm{~min}$ dialysis of the cell interior with the contents of the recording electrode. All in all, the data provide strong evidence against a detectable contribution of endogenous metabotropic ATP receptors to the responses described in this study.

We next studied $\mathrm{Ca}^{2+}$ flux at homomeric rat P2X channels. ATP evoked inward currents and measurable decreases in fluorescence of fura-2 at $380 \mathrm{~nm}\left(\Delta F_{380}\right)$ in cells expressing functional homomeric P2X channels (Fig. 4). In all cases, the time course of the change in fluorescence paralleled the accumulation of charge $\left(Q_{\mathrm{T}}\right)$, as expected if the underlying cause of the rise in $\mathrm{Ca}^{2+}$ is the ATP-gated current. Pf\% values determined for all six functional rat homomeric channels were as follows: $\mathrm{P}_{2}, 12.4 \pm 1.6 \%(n=$ 5); $\mathrm{P}_{2} \mathrm{X}_{2}, 5.7 \pm 0.3 \%(n=18) ; \mathrm{P}_{2} \mathrm{X}_{3}, 2.7 \pm 0.9 \%(n=5) ; \mathrm{P}_{2} \mathrm{X}_{4}$, $11.0 \pm 0.7 \%(n=14) ; \mathrm{P}_{2} \mathrm{X}_{5}, 4.5 \pm 0.5 \%(n=5) ;$ and $\mathrm{P} 2 \mathrm{X}_{7}, 4.6 \pm$ $0.5 \%(n=12)$. We found that $\mathrm{Pf} \%$ was not a function of agonist concentration for $\mathrm{P} 2 \mathrm{X}_{2}$ channels $(5.8 \pm 0.3,5.5 \pm 0.5$, and $6.3 \pm$ $0.9 \%$ for 10,30 , and $100 \mu \mathrm{M}$ ATP, respectively, $n=13,4$, and 3 , respectively; $p>0.05$ ), although we did not study this relationship in detail for all channels. With the exception of the $\mathrm{P}_{2} \mathrm{X}_{3}$ channel, all ATP-gated channels show fractional $\mathrm{Ca}^{2+}$ currents that are equal to or greater than $\alpha 4 \beta 2,5-\mathrm{HT}_{3 \mathrm{~A}}$, and VR1 channels (Fig. 5A). Furthermore, both $\mathrm{P}_{2} \mathrm{X}_{1}$ and $\mathrm{P}_{2} \mathrm{X}_{4}$ channels display fractional $\mathrm{Ca}^{2+}$ currents that are equivalent $(p>0.05)$ to the NR1/NR2A NMDA channel that was thought previously to be an unparalleled source of transmitter-activated $\mathrm{Ca}^{2+}$ flux. The human homologues, $\mathrm{hP} 2 \mathrm{X}_{1}$ and $\mathrm{hP} 2 \mathrm{X}_{4}$, also gate large fractional $\mathrm{Ca}^{2+}$ currents of $10.8 \pm 1.1 \%(n=7)$ and $15.0 \pm 1.5 \%(n=7)$, respectively, demonstrating that high $\mathrm{Ca}^{2+}$ flux is conserved across species.
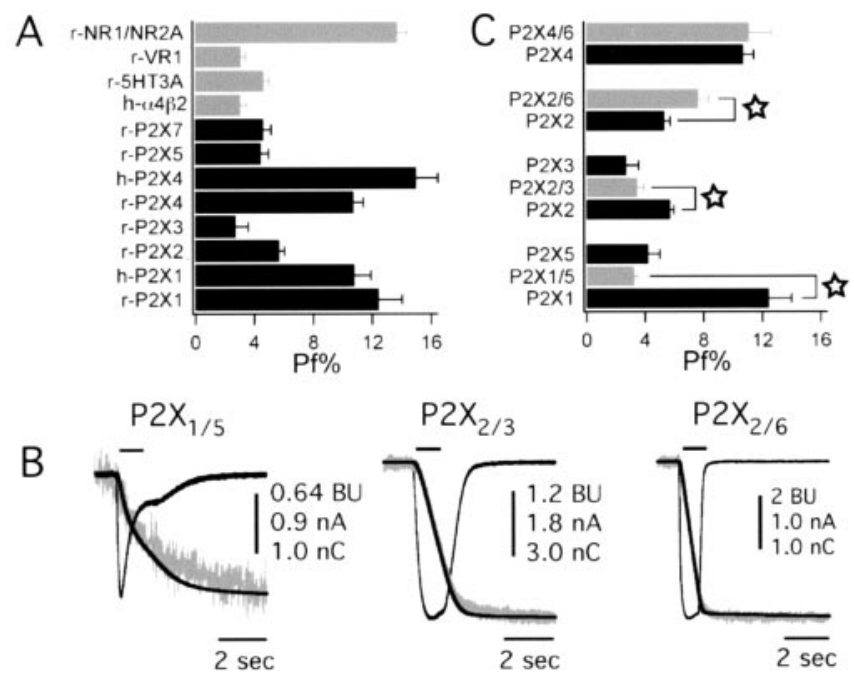

Figure 5. Fractional $\mathrm{Ca}^{2+}$ currents for transmitter-gated channels. A, Mean data for Pf $\%$ of TGCCs compared with homomeric rat and human P2X channels. Note there is no data point for

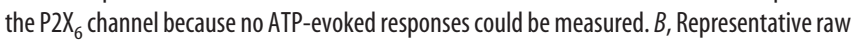
data of three heteromeric rat P2X channels. These traces show ATP-evoked currents (black), $Q_{T}$

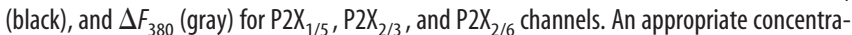
tion of ATP (either 3 or $30 \mu \mathrm{m}$ ) for each channel was used to evoke current. $C$, Mean data for the measured Pf\% values for ATP-evoked currents recorded from cells expressing combinations of P2X subunits. The stars indicate significant differences between the heteromeric assemblies and their homomeric counterparts.

\section{Pf\% for heteromeric P2X channels gated by ATP}

We next cotransfected HEK293 cells with pairs of cDNAs to record the $\mathrm{Pf} \%$ values of heteromeric rat $\mathrm{P} 2 \mathrm{X}$ channels (Fig. $5 B$ ). Four pairs of subunits $\left(\mathrm{P} 2 \mathrm{X}_{1 / 5}, \mathrm{P} 2 \mathrm{X}_{2 / 3}, \mathrm{P} 2 \mathrm{X}_{2 / 6}\right.$, and $\left.\mathrm{P} 2 \mathrm{X}_{4 / 6}\right)$ are known to form functional complexes (North, 2002). The current through two of these pairs, $\mathrm{P}_{2} \mathrm{X}_{1 / 5}$ and $\mathrm{P} 2 \mathrm{X}_{2 / 3}$, can be reliably measured without significant contamination by the unpaired, homomeric channels that may also be expressed. Cotransfection of $\mathrm{P} 2 \mathrm{X}_{1}$ and $\mathrm{P} 2 \mathrm{X}_{5}$ produces a population of channels composed almost exclusively of heteromeric $\mathrm{P} 2 \mathrm{X}_{1 / 5}$ channels (Torres et al., 1998). The Pf\% of heteromeric $\mathrm{P} 2 \mathrm{X}_{1 / 5}$ channels was $3.3 \pm 0.2 \%$ $(n=9)$, a value similar to homomeric $\mathrm{P}_{2} \mathrm{X}_{5}$ channels (Fig. $5 C$ ). Cells cotransfected with cDNAs for $\mathrm{P}_{2} \mathrm{X}_{2}$ and $\mathrm{P} 2 \mathrm{X}_{3}$ were studied using $\alpha \beta$-methylene ATP to isolate heteromeric responses (North, 2002). The Pf\% of heteromeric P2X $\mathrm{X}_{2 / 3}$ channels was $3.5 \pm 0.5 \%(n=9)$. In both cases, the heteromeric channels show the $\mathrm{Ca}^{2+}$ phenotype of the less permeable channel. Functional isolation of heteromeric $\mathrm{P}_{2} \mathrm{X}_{2 / 6}$ and $\mathrm{P} 2 \mathrm{X}_{4 / 6}$ responses from possible homomeric channels is less straightforward because there are no agonists that separate homomeric $\mathrm{P}_{2} \mathrm{X}_{2}$ channels from the heteromeric pairs (North, 2002). However, we found that cotransfection of cDNAs encoding $\mathrm{P}_{2} \mathrm{X}_{2}$ and $\mathrm{P} 2 \mathrm{X}_{6}$ subunits produced a population of ATP-gated channels that had a Pf\% that was significantly greater $(7.7 \pm 0.7 \% ; n=14)$ than that of the $\mathrm{P}_{2} \mathrm{X}_{2}$ channel alone $(p=0.0074)$ (Fig. $\left.5 C\right)$, and these data suggest that a considerable percentage of this channel population is heteromeric (King et al., 2000). Seemingly, the $\mathrm{P}_{2} \mathrm{X}_{6}$ subunit imparts a sizable increase in $\mathrm{Ca}^{2+}$ flux through the pore. In contrast, cotransfection of rat $\mathrm{P} 2 \mathrm{X}_{4}$ and $\mathrm{P} 2 \mathrm{X}_{6} \mathrm{cDNAs}$ resulted in an ATPevoked current with a Pf\% $(11.3 \pm 1.0 \% ; n=6)$ not significantly different from transfection of rat $\mathrm{P}_{2} \mathrm{X}_{4} \mathrm{cDNA}$ alone, although it is possible that our measurement of $\mathrm{Pf} \%$ at $\mathrm{P} 2 \mathrm{X}_{4 / 6}$ channels may be dominated by homomeric $\mathrm{P}_{2} \mathrm{X}_{4}$ channels that are likely also expressed. 


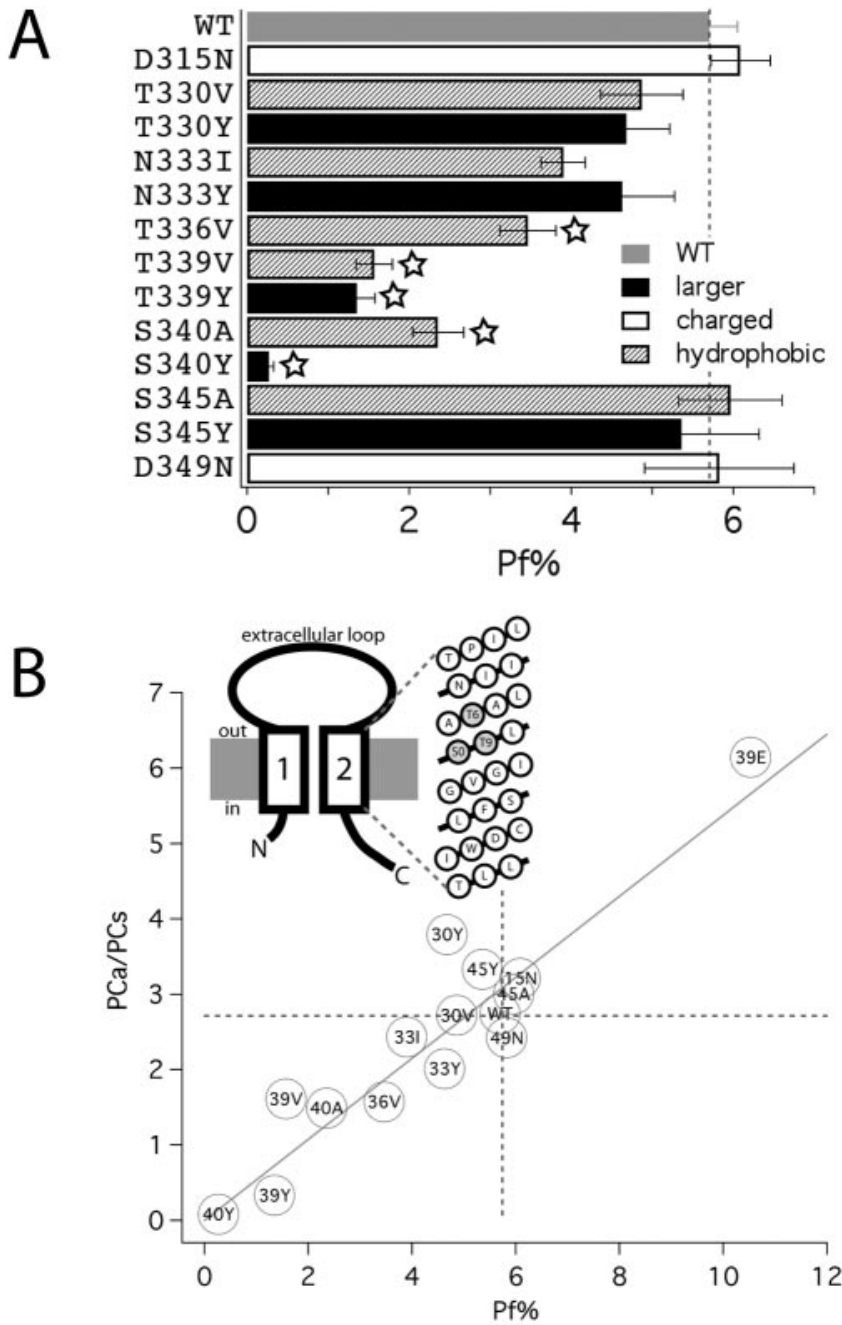

Figure 6. Toward a molecular basis for high $\mathrm{Ca}^{2+}$ flux at $\mathrm{P} 2 \mathrm{X}_{2}$ channels. $A$, The bar graph shows $\mathrm{Pf} \%$ values for $\mathrm{P} 2 \mathrm{X}_{2}$ mutants, as indicated with amino acids substituted for changes in side chain size, charge, and hydrophobicity. WT, Wild type. The stars indicate statistical significance. $B$, The diagram illustrates the presently understood membrane topology of a P2X subunit and a helical net model of the second transmembrane segment. The secondary structure of TM2 is unknown, although it is not unreasonable to assume that this segment conforms to a general pattern of helical, pore-forming domains of other ion channels (Spencer and Rees, 2002). If so, then the residues influencing Pf $\%$ at P2X channels cluster on one face of a predicted $\alpha$ helix, perhaps representing the molecular determinants of a $\mathrm{Ca}^{2+}$ selectivity filter. The graph shows the relative $P_{C_{a}} / P_{C s}$ data by Migita et al. (2001) plotted against the Pf $\%$ data shown in $B$. For the sake of clarity, mutants are designated by the last two digits of their position in the sequence of $\mathrm{P} 2 \mathrm{X}_{2}$ and by a letter code designating the substituted amino acid. For example, $\mathrm{T} 339 \mathrm{Y}$ is designated as $39 \mathrm{Y}$. Also included are permeability and $\mathrm{Pf} \%$ data for the mutant T339E. This mutant showed elevated $\mathrm{Ca}^{2+}$ permeability and flux, as expected after addition of fixed negative charge to a critical position within the pore (Heinemann et al., 1992).

\section{On the role of pore lining polar residues in determining $\mathrm{Ca}^{2+}$} flux at $\mathrm{P} 2 \mathrm{X}_{2}$ channels

The high $\mathrm{Ca}^{2+}$ flux at nicotinic and NMDA channels occurs because of fixed charge in the pore region that may concentrate or select $\mathrm{Ca}^{2+}$ ions for permeation (Premkumar and Auerbach, 1996; Sharma and Stevens, 1996; Burnashev, 1998; Unwin, 2000; Watanabe et al., 2002). How do the structurally distinct P2X channels select for $\mathrm{Ca}^{2+}$ ions over the equally sized but $\sim 100$ fold more abundant $\mathrm{Na}^{+}$? We focused on the involvement of the second transmembrane domain (TM2) (Fig. 6A) because it lines the channel pore (North, 2002) and ion permeation is altered in TM2 mutants (Migita et al., 2001). We focused on homomeric
P2X $\mathrm{X}_{2}$ channels because most of our understanding of P2X channel structure and function is derived from studies of these channels, and this wealth of data provides an appropriate framework for hypothesis-driven mutagenesis (North, 2002). P2X channels contain conserved aspartates that may occupy sites near the pore vestibules. However, we believe that these aspartates do not make an obvious contribution to $\mathrm{Ca}^{2+}$ flux because neutralizing the negative charge at D315 and D349 with asparagines had no effect on $\mathrm{Pf} \%$ values of $\mathrm{P} 2 \mathrm{X}_{2}$ channels (Fig. $6 \mathrm{~B}$ ). Next, we systematically mutated the polar amino acids that may provide a favorable environment for ion flow through the channel. Changing the character of polar residues that are primarily external (T330 and $\mathrm{N} 333$ ) or immediately internal (S345) to the putative channel gate near G342-V343-G344 (North, 2002) produced little effect on $\mathrm{Ca}^{2+}$ flux. However, increasing the hydrophobicity of three critical amino acids just extracellular to the gate (T336, T339, and S340) led to significant decreases in Pf\%, suggesting that permeating ions normally interact with these polar residues in this domain. This would likely only occur in a narrow region of the pore. In keeping with this hypothesis, we found that increasing the size of these same amino acids led to either near complete absence of $\mathrm{Ca}^{2+}$ flux (T339Y and S340Y) or less informatively loss of channel function (T336Y). These data are in accord with the findings of Migita et al. (2001) (Fig. 6C), but, because our measurements report $\mathrm{Ca}^{2+}$ flow directly, they provide unequivocal evidence for a domain that regulates $\mathrm{Ca}^{2+}$ flux, just external to the gate, in the pore of $\mathrm{P} 2 \mathrm{X}_{2}$ channels.

\section{Discussion}

Because P2X channels are widely expressed in excitable and nonexcitable cells throughout the body (Norenberg and Illes, 2000; North, 2002; Schwiebert and Zsembery, 2003), it is important to understand the magnitude and mechanisms of ion flow through their pores. Several laboratories have quantified $\mathrm{Ca}^{2+}$ movement through the pores of some, but not all, P2X channels by measuring the relative permeability of $\mathrm{Ca}^{2+}$ to a reference monovalent cation (called $P_{\mathrm{Ca}} / P_{\mathrm{M}}$ ), with the reported values ranging from $\sim 1$ to 4 for different members of the family (for review, see North, 2002). Many of these studies used different extracellular and intracellular concentrations of ions, different values for ion activities, and different algorithms to calculate relative permeability. Thus, it is not possible to directly compare values between studies, and consequently a precise understanding of $\mathrm{Ca}^{2+}$ flux for the P2X family in relation to other channels has been lacking. Here, we used a single, direct and model-independent method and a uniform set of physiological ionic conditions to quantify $\mathrm{Ca}^{2+}$ flux through all known homomeric and heteromeric P2X channels in relation to other transmitter-gated channels. We find that $\mathrm{Ca}^{2+}$ flux ranges from $\sim 3$ to $15 \%$ of total current through the $\mathrm{P} 2 \mathrm{X}$ pore in a manner that depends on the subunit composition of protein. This corresponds to $P_{\mathrm{Ca}} / P_{\mathrm{M}}$ values between $\sim 1$ and 3 if current follows constant field assumptions (Burnashev et al., 1995).

The main finding of the present study is that ATP-gated channels conduct an unexpectedly large flux of $\mathrm{Ca}^{2+}$ across cell surface membranes at resting membrane potentials in physiological solutions. As a family, P2X channels conduct more $\mathrm{Ca}^{2+}$ on average than do ACh, proton, serotonin, or glutamate-gated channels. Furthermore, the fractional $\mathrm{Ca}^{2+}$ current at the brain forms of $\mathrm{P} 2 \mathrm{X}$ channels $\left(\mathrm{P} 2 \mathrm{X}_{2}, \mathrm{P} 2 \mathrm{X}_{4}, \mathrm{P} 2 \mathrm{X}_{2 / 6}\right.$, and perhaps $\left.\mathrm{P} 2 \mathrm{X}_{4 / 6}\right)$ at $\sim 6-14 \%$ is significantly larger than that of AMPA $(\sim 0.5-3.9 \%)$ and kainate channels $(\sim 0.2-2 \%)$ (Burnashev et al., 1995), and, in the case of $\mathrm{P} 2 \mathrm{X}_{2}$, similar to that of $\mathrm{P} 2 \mathrm{X}$ channels in sympathetic 


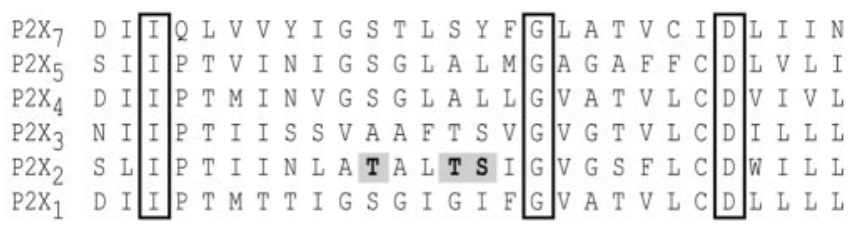

Figure 7. Sequence alignment of the putative second transmembrane segments of $P 2 X$ subunits. A stretch of 28 adjoining amino acids thought to span the membrane is shown for each of the six functional homomeric channels. The boxed amino acids are identical in all family members. Mutations of the three shaded amino acids of the $\mathrm{P} 2 \mathrm{X}_{2}$ channel result in changes in $\mathrm{Pf} \%$.

neurons (Rogers and Dani, 1995). Several P2X channels (P2X $\mathrm{P} 2 \mathrm{X}_{4}, \mathrm{P} 2 \mathrm{X}_{2 / 6}$ and perhaps $\mathrm{P}_{2} \mathrm{X}_{4 / 6}$ ) display fractional calcium currents between $\sim 8$ and $15 \%$ that are larger than those of $\alpha 7$ nicotinic channels (Fucile et al., 2003) and equal to or greater than distinct NMDA channels at 8-14\% (Burnashev et al., 1995). Furthermore, $\mathrm{Ca}^{2+}$ inflow through NMDA channels decreases at potentials more negative than $-30 \mathrm{mV}$ because of $\mathrm{Mg}^{2+}$ block of the pore (Burnashev et al., 1995), whereas this does not occur for $\mathrm{P} 2 \mathrm{X}$ channels. Thus, it is likely that $\mathrm{Ca}^{2+}$ flux through P2X channels may dominate over NMDA channels at resting membrane potentials when $\mathrm{Mg}^{2+}$ blocks the NMDA channel. Furthermore, our data indicate that, in contrast to nicotinic and glutamate channels, $\mathrm{P} 2 \mathrm{X}_{2}$ channels may not use rings of fixed charge to select $\mathrm{Ca}^{2+}$. Rather, a critical domain (Migita et al., 2001) in the center of the pore influences $\mathrm{Ca}^{2+}$ flux (Fig. 6). Although the precise mechanism of ion selection is unknown, polar amino acids may provide the countercharge needed to partially dehydrate $\mathrm{Ca}^{2+}$ ions in a narrow part of the pore. At present, we do not know if this countercharge is supplied by backbone carbonyl oxygens, as is the case for $\mathrm{K}^{+}$channels (Doyle et al., 1998), or directly by the side chains themselves. Indeed, the lack of sequence conservation in this domain among the family favors the latter hypothesis (Fig. 7). However, unlike the side chains of the amino acids that constitute the selectivity filter of $\mathrm{K}^{+}$channels, the side chains of T336, T339, and S340 of the P2X $\mathrm{X}_{2}$ channel face into the aqueous environment of the pore (Egan et al., 1998) and therefore are well positioned to influence the flow of ions across the membrane. Different members of the family display a variable $\mathrm{Ca}^{2+}$ flux, and it will be interesting to see whether this range reflects the sequence variability in TM2. Future experiments designed to study the effects of site-directed mutagenesis at homologous sites of other family members are needed before a complete hypothesis about the mechanics of calcium permeability and flux can be presented. Furthermore, it is not apparent in the sequences presented in Figure 7 why the $\mathrm{P}_{2} \mathrm{X}_{1}$ and $\mathrm{P} 2 \mathrm{X}_{4}$ channels should have such extraordinarily high $\mathrm{Ca}^{2+}$ fluxes; the explanation may reside at distant sites An obvious place to look would be TM1 because it, like TM2, is thought to line the pore (North, 2002). Alternatively, $\mathrm{Ca}^{2+}$ may be selected by parts of the protein besides the transmembrane domains. The identity of these distant sites may remain hidden until the structure of the channel is solved.

The present experiments on molecularly defined channels now call for similar experiments on endogenously expressed P2X channels in brain neurons. From this perspective, we note that previous estimates of Pf\% for NMDA channels endogenously expressed in brain neurons (Schneggenburger et al., 1993), and heterologously expressed in HEK293 cells (Burnashev et al., 1995; Watanabe et al., 2002) differ by $\sim 7 \%$, perhaps suggesting that presently unknown factors in neurons may regulate Pf\%. It will be interesting to determine whether a similar situation exists for natively expressed P2X channels. The experiments with native $\mathrm{P} 2 \mathrm{X}$ channels in brain neurons are challenging because not all neurons express P2X channels. Moreover, our recent systematic analysis of P2X channel expression in different fields of the hippocampus suggests that $\mathrm{P} 2 \mathrm{X}$ channels may be trafficked to nerve terminals and dendrites rather than being expressed in the soma (Khakh et al., 2003). An additional consideration is that it is difficult to discriminate distinct P2X channels from each other because of the paucity of selective agonists and antagonists (Khakh et al., 2001). This problem is heightened by the fact that most neurons contain mRNA for multiple, and in some cases all, P2X subunits (Collo et al., 1996; North, 2002), suggesting that neurons may express mixtures of distinct P2X channels on their surfaces. However, our estimate of $\mathrm{Pf} \%$ at $\sim 6 \%$ for $\mathrm{P} 2 \mathrm{X}_{2}$ is consistent with that measured previously for natively expressed P2X 2 -like channels in SCG neurons (Rogers and Dani, 1995). The highest $\mathrm{Pf} \%$ values for $\mathrm{P}_{2} \mathrm{X}_{4}$ and $\mathrm{P}_{2} \mathrm{X}_{1}$ at $10-15 \%$ channels are also broadly consistent with previous estimates at $15 \%$ from medial habenula neurons on the basis of reversal potentials (Edwards et al., 1997). Our demonstration of high $\mathrm{Ca}^{2+}$ flux for the whole P2X channel family offers a molecular interpretation of several physiological responses. Recent elegant studies show profound $\mathrm{P}_{2} \mathrm{X}_{1}$ channel-mediated changes in intracellular $\mathrm{Ca}^{2+}$ in smooth muscle cells during fast ATP synaptic transmission (Brain et al., 2002; Lamont and Wier, 2002; Lamont et al., 2003). $\mathrm{P}_{2} \mathrm{X}_{1}$ channels are well suited to this task because they are a large source of transmitter-activated $\mathrm{Ca}^{2+}$ flux (Fig. 4). The diverse presynaptic and postsynaptic effects of ATP on synaptic transmission and long-term potentiation (MacDermott et al., 1999; North, 2002) may be explained by variable expression of different $\mathrm{P} 2 \mathrm{X}$ subunits and the associated differences in $\mathrm{Ca}^{2+}$ flux. P2X channels are also abundantly expressed in non-excitable cells, including epithelia, astrocytes, and microglia (Inoue, 2002; Schwiebert and Zsembery, 2003), in which the physiological response may be triggered by $\mathrm{Ca}^{2+}$ entry rather than a depolarization. Thus, $\mathrm{P}_{2} \mathrm{X}_{4}$ channel activation in epithelial cells results in sustained $\mathrm{Ca}^{2+}$ entry that may trigger $\mathrm{Cl}^{-}$secretion and prove to be of benefit in cystic fibrosis (Zsembery et al., 2003). Interestingly, recent studies show that upregulated P2X channels in microglia may trigger the release of factors such as cytokines and trigger allodynia (Tsuda et al., 2003). It is possible that the trigger for this is likely to be the substantial $\mathrm{Ca}^{2+}$ entry through $\mathrm{P}_{2} \mathrm{X}_{4}$ subunit-containing channels. Mutant P2X channels with calibrated $\mathrm{Ca}^{2+}$ fluxes like those reported here could be used to further explore this possibility in vitro and in vivo and possibly in genetic approaches to treat P2X channel-associated pathologies (Tsuda et al., 1999, 2000, 2003). P2X channel subunits have been localized to brain nerve terminals (Vulchanova et al., 1996; Vulchanova et al., 1997; Le et al., 1998; MacDermott et al., 1999) and the periphery of dendritic spines (Rubio and Soto, 2001) by light and electron microscopy. Synaptically released ATP acting on $\mathrm{P}_{2} \mathrm{X}_{1}$ channels evokes postsynaptic $\mathrm{Ca}^{2+}$ changes (Brain et al., 2002; Lamont and Wier, 2002; Lamont et al., 2003), and exogenous and endogenously released ATP causes a form of $\mathrm{Ca}^{2+}$. dependent presynaptic facilitation at some interneuron synapses (Khakh et al., 2003). Our data indicating that distinct P2X channels support significant, but variable, $\mathrm{Ca}^{2+}$ flux provides a molecular interpretation of these physiological studies and a rational to determine whether ATP gates a $\mathrm{Ca}^{2+}$ pathway in single dendritic spines that are known to express P2X channels (Rubio and Soto, 2001). 


\section{References}

Alonzo MT, Chamero P, Villalobos C, Garcia-Sancho J (2003) Fura-2 antagonises calcium-induced calcium release. Cell Calcium 33:27-35.

Benham CD, Tsien RW (1987) A novel receptor-operated $\mathrm{Ca}^{2+}$-permeable channel activated by ATP in smooth muscle. Nature 328:275-278.

Berridge MJ, Bootman MD, Roderick HL (2003) Calcium signalling: dynamics, homeostasis and remodelling. Nat Rev Mol Cell Biol 4:517-529.

Brain KL, Jackson VM, Trout SJ, Cunnane TC (2002) Intermittent ATP release from nerve terminals elicits focal smooth muscle $\mathrm{Ca}^{2+}$ transients in mouse vas deferens. J Physiol (Lond) 541:849-862.

Burnashev N (1998) Calcium permeability of ligand-gated channels. Cell Calcium 24:325-332.

Burnashev N, Zhou Z, Neher E, Sakmann B (1995) Fractional calcium currents through recombinant GluR channels of the NMDA, AMPA and kainate receptor subtypes. J Physiol (Lond) 485:403-418.

Collo G, North RA, Kawashima E, Merlo-Pich E, Neidhart S, Surprenant A, Buell G (1996) Cloning of $\mathrm{P} 2 \mathrm{X}_{5}$ and $\mathrm{P} 2 \mathrm{X}_{6}$ receptors and the distribution and properties of an extended family of ATP-gated ion channels. J Neurosci 16:2495-2507.

Doyle DA, Cabral JM, Pfuetzner RA, Kuo A, Gulbis JM, Cohen SL, Chait BT, MacKinnon R (1998) The structure of the potassium channel: molecular basis of $\mathrm{K}^{+}$conduction and selectivity. Science 280:69-77.

Edwards FA, Robertson SJ, Gibb AJ (1997) Properties of ATP receptormediated synaptic transmission in the rat medial habenula. Neuropharmacology 36:1253-1268.

Egan TM, Haines WR, Voigt MM (1998) A domain contributing to the ion channel of ATP-gated $\mathrm{P}_{2} \mathrm{X}_{2}$ receptors identified by the substituted cysteine accessibility method. J Neurosci 18:2350-2359.

Fischer W, Wirkner K, Weber M, Eberts C, Koles L, Reinhardt R, Franke H, Allgaier C, Gillen C, Illes P (2003) Characterization of P2X3, P2Y1 and P2Y4 receptors in cultured HEK293-hP2X3 cells and their inhibition by ethanol and trichloroethanol. J Neurochem 85:779-790.

Frings S, Hackos DH, Dzeja C, Ohyama T, Hagen V, Kaupp UB, Korenbrot JI (2000) Determination of fractional calcium ion current in cyclic nucleotide-gated channels. Methods Enzymol 315:797-817.

Fucile S, Renzi M, Lax P, Eusebi F (2003) Fractional $\mathrm{Ca}^{2+}$ current through human neuronal alpha7 nicotinic acetylcholine receptors. Cell Calcium 34:205-209.

Galligan JJ, Bertrand PP (1994) ATP mediates fast synaptic potentials in enteric neurons. J Neurosci 14:7563-7571.

Green T, Heinemann SF, Gusella JF (1998) Molecular neurobiology and genetics: investigation of neural function and dysfunction. Neuron 20:427-444.

Gu JG, MacDermott AB (1997) Activation of ATP P2X receptors elicits glutamate release from sensory neuron synapses. Nature 389:749-753.

He ML, Zemkova H, Koshimizu TA, Tomic M, Stojilkovic SS (2003) Intracellular calcium measurements as a method in studies on activity of purinergic P2X receptor-channels. Am J Physiol Cell Physiol 285:C467-C479.

Heinemann SH, Terlau H, Stuhmer W, Imoto K, Numa S (1992) Calcium channel characteristics conferred on the sodium channel by single mutations. Nature 356:441-443.

Hugel S, Schlichter R (2000) Presynaptic P2X receptors facilitate inhibitory GABAergic transmission between cultured rat spinal cord dorsal horn neurons. J Neurosci 20:2121-2130.

Inoue K (2002) Microglial activation by purines and pyrimidines. Glia 40:156-163.

Jatzke C, Watanabe J, Wollmuth LP (2002) Voltage and concentration dependence of $\mathrm{Ca}^{2+}$ permeability in recombinant glutamate receptor subtypes. J Physiol (Lond) 538:25-39.

Jiang LH, Kim M, Spelta V, Bo X, Surprenant A, North RA (2003) Subunit arrangement in P2X receptors. J Neurosci 23:8903-8910.

Kato F, Shigetomi E (2001) Distinct modulation of evoked and spontaneous EPSCs by purinoceptors in the nucleus tractus solitarii of the rat. J Physiol (Lond) 530:469-486.

Khakh BS (2001) Molecular physiology of P2X receptors and ATP signalling at synapses. Nat Rev Neurosci 2:165-174.

Khakh BS, Henderson G (1998) ATP receptor-mediated enhancement of fast excitatory neurotransmitter release in the brain. Mol Pharmacol 54:372-378.

Khakh BS, Zhou X, Sydes J, Galligan JJ, Lester HA (2000) State-dependent cross-inhibition between transmitter-gated cation channels. Nature 406:405-410.

Khakh BS, Burnstock G, Kennedy C, King BF, North RA, Seguela P, Voigt M, Humphrey PPA (2001) International Union of Pharmacology. XXIV. Current status of the nomenclature and properties of $\mathrm{P} 2 \mathrm{X}$ receptors and their subunits. Pharmacol Rev 53:107-118.

Khakh BS, Gitterman DP, Cockayne D, Jones AM (2003) ATP modulation of excitatory synapses onto interneurons. J Neurosci 23:7426-7437.

King BF, Townsend-Nicholson A, Wildman SS, Thomas T, Spyer KM, Burnstock G (2000) Coexpression of rat P2X $\mathrm{X}_{2}$ and $\mathrm{P} 2 \mathrm{X}_{6}$ subunits in Xenopus oocytes. J Neurosci 20:4871-4877.

Lamont C, Wier WG (2002) Evoked and spontaneous purinergic junctional $\mathrm{Ca}^{2+}$ transients (jCaTs) in rat small arteries. Circ Res 91:454-456.

Lamont C, Vainorius E, Wier WG (2003) Purinergic and adrenergic $\mathrm{Ca}^{2+}$ transients during neurogenic contractions of rat mesenteric small arteries. J Physiol (Lond) 549:801-808.

Lax P, Fucile S, Eusebi F (2002) $\mathrm{Ca}^{2+}$ permeability of human heteromeric nAChRs expressed by transfection in human cells. Cell Calcium 32:53-58

Le KT, Villeneuve P, Ramjaun AR, McPherson PS, Beaudet A, Seguela P (1998) Sensory presynaptic and widespread somatodendritic immunolocalization of central ionotropic P2X ATP receptors. Neuroscience 83:177-190.

MacDermott AB, Role LW, Siegelbaum SA (1999) Presynaptic ionotropic receptors and the control of transmitter release. Annu Rev Neurosci 22:443-485.

Migita K, Haines WR, Voigt MM, Egan TM (2001) Polar residues of the second transmembrane domain influence cation permeability of the ATP-gated $\mathrm{P}_{2} \mathrm{X}_{2}$ receptor. J Biol Chem 276:30934-30941.

Montell C (2001) Physiology, phylogeny, and functions of the TRP superfamily of cation channels. SciSTKE 2001:RE1.

Nakatsuka T, Gu JG (2001) ATP P2X receptor-mediated enhancement of glutamate release and evoked EPSCs in dorsal horn neurons of the rat spinal cord. J Neurosci 21:6522-6531.

Nicke A, Baumert HG, Rettinger J, Eichele A, Lambrecht G, Mutschler E, Schmalzing $\mathrm{G}$ (1998) $\mathrm{P} 2 \mathrm{X}_{1}$ and $\mathrm{P}_{2} \mathrm{X}_{3}$ receptors form stable trimers: a novel structural motif of ligand-gated ion channels. EMBO J 17:3016-3028.

Norenberg W, Illes P (2000) Neuronal P2X receptors: localisation and functional properties. Naunyn Schmiedebergs Arch Pharmacol 362:324-339.

North RA (2002) Molecular physiology of P2X receptors. Physiol Rev 82:1013-1067.

Premkumar LS, Auerbach A (1996) Identification of a high affinity divalent cation binding site near the entrance of the NMDA receptor channel. Neuron 16:869-880.

Ragozzino D, Barabino B, Fucile S, Eusebi F (1998) $\mathrm{Ca}^{2+}$ permeability of mouse and chick nicotinic acetylcholine receptors expressed in transiently transfected human cells. J Physiol (Lond) 507:749-757.

Rassendren F, Buell G, Newbolt A, North RA, Surprenant A (1997) Identification of amino acid residues contributing to the pore of a $\mathrm{P} 2 \mathrm{X}$ receptor. EMBO J 16:3446-3454.

Reeves DC, Lummis SC (2002) The molecular basis of the structure and function of the 5-HT3 receptor: a model ligand-gated ion channel [review]. Mol Membr Biol 19:11-26.

Ren J, Bian X, DeVries M, Schnegelsberg B, Cockayne DC, Ford AP, Galligan JJ (2003) P2X2 subunits contribute to fast synaptic excitation in myenteric neurons of the mouse small intestine. J Physiol (Lond) 552:809-821.

Rogers M, Dani JA (1995) Comparison of quantitative calcium flux through NMDA, ATP, and ACh receptor channels. Biophys J 68:501-506.

Rubio ME, Soto F (2001) Distinct localisation of $\mathrm{P} 2 \mathrm{X}$ receptors at excitatory postsynaptic specializations. J Neurosci 21:641-653.

Schneggenburger R (1998) Altered voltage dependence of fractional $\mathrm{Ca}^{2+}$ current in $N$-methyl-D-aspartate channel pore mutants with a decreased $\mathrm{Ca}^{2+}$ permeability. Biophys J 74:1790-1794.

Schneggenburger R, Zhou Z, Konnerth A, Neher E (1993) Fractional contribution of calcium to the cation current through glutamate receptor channels. Neuron 11:133-143.

Schwiebert EM, Zsembery A (2003) Extracellular ATP as a signaling molecule for epithelial cells. Biochim Biophys Acta 1615:7-32.

Sharma G, Stevens CF (1996) Interactions between two divalent ion binding sites in $N$-methyl-D-aspartate receptor channels. Proc Natl Acad Sci USA 93:14170-14175.

Spencer RH, Rees DC (2002) The alpha-helix and the organization and gating of channels. Annu Rev Biophys Biomol Struct 31:207-233. 
Stoop R, Thomas S, Rassendren F, Kawashima E, Buell G, Surprenant A, North R (1999) Contribution of individual subunits to the multimeric $\mathrm{P} 2 \mathrm{X}_{2}$ receptor: estimates based on methanethiosulfonate block at T336C. Mol Pharmacol 56:973-981.

Torres GE, Haines WR, Egan TM, Voigt MM (1998) Co-expression of P2x1 and $\mathrm{P} 2 \mathrm{x} 5$ receptor subunits reveals a novel ATP-gated ion channel. Mol Pharmacol 54:989-993.

Tsuda M, Ueno S, Inoue K (1999) Evidence for the involvement of spinal endogenous ATP and $\mathrm{P} 2 \mathrm{X}$ receptors in nociceptive responses caused by formalin and capsaicin in mice. Br J Pharmacol 128:1497-1504.

Tsuda M, Koizumi S, Kita A, Shigemoto Y, Ueno S, Inoue K (2000) Mechanical allodynia caused by intraplantar injection of $\mathrm{P} 2 \mathrm{X}$ receptor agonist in rats: involvement of heteromeric $\mathrm{P}_{2} \mathrm{X}_{2 / 3}$ receptor signaling in capsaicininsensitive primary afferent neurons. J Neurosci 20:RC90(1-5).

Tsuda M, Shigemoto-Mogami Y, Koizumi S, Mizokoshi A, Kohsaka S, Salter MW, Inoue K (2003) P2X4 receptors induced in spinal microglia gate tactile allodynia after nerve injury. Nature 424:778-783.
Unwin N (2000) The Croonian Lecture 2000. Nicotinic acetylcholine receptor and the structural basis of fast synaptic transmission. Philos Trans R Soc Lond B Biol Sci 355:1813-1829.

Vulchanova L, Arvidsson U, Riedl M, Wang J, Buell G, Surprenant A, North RA, Elde R (1996) Differential distribution of two ATP-gated channels (P2X receptors) determined by immunocytochemistry. Proc Natl Acad Sci USA 93:8063-8067.

Vulchanova L, Riedl MS, Shuster SJ, Buell G, Surprenant A, North RA, Elde R (1997) Immunohistochemical study of the $\mathrm{P}_{2} \mathrm{X}_{2}$ and $\mathrm{P} 2 \mathrm{X}_{3}$ receptor subunits in rat and monkey sensory neurons and their central terminals. Neuropharmacology 36:1229-1242.

Watanabe J, Beck C, Kuner T, Premkumar LS, Wollmuth LP (2002) DRPEER: a motif in the extracellular vestibule conferring high $\mathrm{Ca}^{2+}$ flux rates in NMDA receptor channels. J Neurosci 22:10209-10216.

Zsembery A, Boyce AT, Liang L, Peti-Peterdi J, Bell PD, Schwiebert EM (2003) Sustained calcium entry through P2X nucleotide receptor channels in human airway epithelial cells. J Biol Chem 278:13398-13408. 